\title{
Review of soil tillage history and new challenges in Hungary
}

\author{
Márta BIRKÁS, Igor DEKEMATI, Zoltán KENDE and BarnabÁs PÓSA ${ }^{1}$
}

\begin{abstract}
This study provides an overview of the development of soil tillage in Hungary. The primary goal is to present factors that have been promoting and hindering progress in tillage from the first authoritative records - from the eleventh century - up to now when soil tillage became a tool in the climate damage mitigation methods. Progress was restricted during the first eight hundred years of the history of tillage by lack of expertise and the use of primitive tools. In retrospect, much of the traditions are regarded as obstacles to progress while the adoption of certain foreign trends fostered development in most cases. The history of the development of tillage in Hungary is divided into seven eras, with equal positive and negative impacts on the quality of the soils. The quality of soils was threatened before 1900 primarily by the multi-ploughing systems, while reasonable tillage offered a chance for improvement. The geographical location of Hungary in Europe and the Hungarian language entailed a certain degree of isolation as well. It may have been the reason why Hungarian reasonable tillage could not become a forerunner of minimum tillage. New soil tillage methods developed abroad had influenced primarily education and experiments carried out in Hungary. After the regime change, however, such methods came to be driving progress in practice as well, thanks to a widened horizon. In 1998 soil conservation tillage were used on about 25 per cent of the total sown land, however, a decade and a half later the area cultivated by conservation methods had doubled. A survey conducted five years ago found that significant progress had been made in soil conservation tillage in dry seasons but the achievements are often eroded by return to the conventional modes during wet seasons.
\end{abstract}

Keywords: conventional tillage, tillage development, soil conservation, climate focused tillage

\section{Introduction}

No critical discussion of the development of soil tillage in Hungary has ever been published in English so far, apart from details (Birkás, M. et al. 1989, 2004), from which is hardly to draw comprehensive conclusions for the reasons why local tillage practices are lagging behind or how progress has been made. The development of tillage techniques in Hungary, respect for tillage in general, its position in the system of cropping, the efforts made at conservation the soil along with the acceptance of new approaches, have always been substantially affected by traditions (Szabó, J. 1909; Sedlmayr, K. 1954). This influence has - in view of contemporary articles and periodicals in various phases of the soil tillage history - more frequently hindered than encouraged the adoption of new techniques (PÁter, K. 1953).

Birkás, M. (2008) gave an overview on the history of soil tillage and pointed the facts that obstructed the progress over centuries, such as the traditions stuck to the multiploughing practice; refused adoption the reversible plough for centuries (however, the first horse-drawn reversible ploughs were introduced in the 1500s); delayed in implementing the improvement of orthodox plough; rejected tillage tools other than the plough without even giving them a try e.g. the Hungarian Plough Planter (Ретнe, F. 1818), the rotavator (1907), disk tiller for alkaline soils (in the 1920s); aversion to use technique of loosening (from 1860 till the

\footnotetext{
${ }^{1}$ Institute of Crop Production, Szent István University, H-2100 Gödöllő, Páter K. u. 1.

E-mails: birkas.marta@mkk.szie.hu, dekemati.igor@mkk.szie.hu, kende.zoltan@mkk.szie.hu, posa.barnabas@mkk.szie.hu
} 
1960s) and blaming the weather instead of recognising soil structure defects; insistence on applying the same old routines instead of learning and adopting new techniques; taking a poor view of soil conserving tillage techniques e.g. cultivators or mulch tillage.

Moreover, Birkás, M. (2008b) listed progressive examples too, such as the 'Hungarian reasonable tillage' strategy, promoted at the end of the 1800s and that was aimed at reducing tillage without increasing the risk of crop production (CSERHÁTI, S. 1900, 1902a,b). Working the soil to the depths exceeding $20 \mathrm{~cm}$ from the year 1860 made a chance to loosen the pans ensued from shallow ploughing (CSERHáti, S. 1891). The first experiments were carried out with reasonable ploughless tillage and the first results were thus achieved in Hungary by Baross, L. (1909) and Manninger, G.A. (1938). At the beginning of the 1920s GYÁRfÁs, J. (1925) gave chance for adoption of the dry farming methods. Kemenesy, E. (1924) was the first scientist to draw attention to the possibilities lying in biological tillage, that is, in keeping the soil in a mellowed state.

The trend of minimum tillage took off in the 1960s, soil conservation was quite negligible as an objective in comparison to efforts made to reduce tillage interventions and minimise tillage costs. The new concept that is soil conservation tillage (SCHERTZ, D.L. 1988) was viewed positively all over the world, including in Hungary.

Mention should also be made of the influence of new foreign tillage tools. Before and during the 1800 s interest focused primarily on the use of ploughs (e.g. Brabant and Hohenheim types and later Sack) constructed abroad. It was in such circumstances that the Kühne factory manufactured of a variety of promising tools, including CAMPBELL's disk and roll. A lot of Russian machines were imported to Hungary after 1945 but there was an upswing in the domestic manufacture of agricultural machinery as well. Farm machinery demonstrations drew attention to high quality products, particularly those that could be reliably operated even under difficult conditions. Progress in soil tillage however, was triggered not so much by the availability of up-to-date machines but the growing demand by farmers, concerning soil condition (Birkás, M. 2008a).

\section{Materials and methods}

\section{Lessons drawn from the history of soil tillage}

This study evokes the most important ideas and conclusions that appeared in articles published earlier on the development of soil tillage and the trends observed in Hungary. Among the information sources, an agricultural journal - namely "Köztelek" - had significant importance considering the well-informative articles, published between 1891 and 1944. "Köztelek" was the main bulletin of the National Hungarian Economic Association (OMGE) and through these publications of the famous classic authors (e. g. Bittera, Cserháti, GyÁrfás, Hensch, Kerpely, Sporzon, Surányi) had wide professional appreciation. In addition, Milhoffer, S. (1897) published useful information - looking back till the Conquest - about contemporary soil management practice and the strange climate extremities.

A critical review of efforts ranging from the earliest ones up to those aiming at reducing the damage caused by climate change is a key part of this paper, along with the tasks to be tackled in the future. Among the cited literature are - in accordance with the objective of this study - dominated the publications by Hungarian authors, primarily those that came out before 1960 .

\section{Investigation of the tillage practice}

Monitoring the tillage practice and the soil condition has started in the end of 1970s (it's going nowadays, too), and covers all soil types located in the different micro regions in Hungary. Main aspects of soil tillage practice monitoring are as follows: advantages and considerations of the ploughing; depth and 
efficiency of the soil loosening; adaptability of the tine tillage by cultivator and considerations of the disk tillage. Surveying the tillage practice - that are conventional, conservation and reduced constraints - delighted in higher attention in the years 1998 and 2011. Monitoring the soil conditions covers: occurrence of the pan compaction; consequences of the outdated tillage traditions on soils; types and seriousness of the tillage and climate (both drought and rain stress) induced soil defects; results of the different soil remediation. Methods of the assessment were presented by BоттLIк, L. et al. 2014. These data and information are widely discussed in the relevant publications, e. g. BirKás, M. et al. 2015a. Machinery dealers and sellers have provided also important - but non-published - information.

\section{Soil and climatic characteristics within Hungary}

The total area of Hungary is 9,303,000 ha, of which $5,346,000$ ha $(57.5 \%)$ is agricultural land, and 4,332,000 ha (46.5\%) is arable land. According to Stefanovits, P. (1981) the topsoil textures of Hungarian soils can be characterised as follows: sand 15 per cent, sandy loam 12 per cent, loam 47 per cent, clay and loamy clay 26 per cent. VÁrALLyAy, Gy. (1989) stressed that approximately 34.8 per cent of the soils are sensitive to degradation and compaction (e. g. Solonetz, Gleysol and Vertisol), 13.9 per cent are non-sensitive (e. g. Calcisol) 23.0 per cent are slightly sensitive (e. g. Arenosol, Cambisol, Histosol) and 28.3 per cent have moderate sensitivity (e. g. Luvisol, Chernozem, Phaeozem).

The climate is continental, although extreme phenomena have occurred more frequently in recent decades. The average annual precipitation decreases from $800 \mathrm{~mm}$ in the west to $500 \mathrm{~mm}$ in the east. During the past decade one year was average, two years were dry, two years were rainy and five years - due to the alternation of the dry and rainy periods - were extreme.

\section{Eras of soil tillage development in Hungary}

The history of soil tillage in Hungary was rich and full of unexpected challenges in the past. The chronological order of the seven main eras in the development of soil tillage as well as their main characteristics, are summed up in Table 1.

Seven eras and the main features of the eras were recorded first by Birkás, M. (1995) and since then only minor changes were

Table 1. Soil tillage development in Hungary (by BIRKÁs, M. 2008)

\begin{tabular}{l|l}
\hline \multicolumn{1}{c}{ Eras of soil tillage development } & \multicolumn{1}{c}{ Main characterization of the era* } \\
\hline 1. Early (-1700) & Lack of tools and expertise $(-)$ \\
\hline 2. Introduction of low intensity farming techniques (1700-1800) & Challenges in crop production $( \pm)$ \\
\hline 3. Multi-ploughing systems (1750-1900) & Soil structure deterioration $(-)$ \\
\hline 4. Reasonable tillage (1860-1920) & Adoption to soil state $(+)$ \\
\hline 5. Conventional tillage (1900-1988) & $\begin{array}{l}\text { High dependence on weather conditions }(-) \\
\text { Adaptability to soil state }(+)\end{array}$ \\
5.1. Classic, based on draught animal (1900-1960) & Crop focusing efforts, deterioration in soil \\
5.2. Temporary, partially mechanized (1920-1970) & quality (-) \\
5.3. Technology focused, fully mechanized (1960-1980) & Soil quality focusing tillage $(+)$ \\
\hline 6. Energy saving and soil conservation tillage (1975-1988 & $\begin{array}{l}\text { Deterioration in soil condition }(-) \\
\text { Climate threats }(-) ;\end{array}$ \\
\hline $\begin{array}{l}\text { 7. Modern adaptable tillage (1988-) } \\
\text { 7.1. Declining period (1988-2000) }\end{array}$ & $\begin{array}{l}\text { New challenges in soil conservation }(+) \\
\text { 7.2. Period of transition (2000-2015) } \\
\text { 7.3. Soil and environment conservation period (?2020- } \\
\text { quality improvement }(+)\end{array}$ \\
\hline
\end{tabular}

*+ progressive, - regressive, \pm both features. 
marked in given table (cf. 2008). In the early era of its development the quality of tillage was determined by the sites gained by clearing forests or grazing lands, by farming that were not suitable for overcoming unfavourable circumstances.

In the era of low intensity farming progress was limited by lack of machines and by a shortage of knowledge. The era of multiploughing tillage was ushered in by the introduction of improved ploughs that were suitable for working the soil to greater depths. This practice has become the bounds of the development considering the deterioration of the soil quality. The principles of reasonable tillage were developed by Cserháti, S. (1900) to reduce detrimental impacts of ploughing up to 3-4 times a year and of excessive manipulation of the soil.

Certain new approaches to tillage, which had been devised abroad and which were radically different from the national practices, arose a wide range of interests. A method named after a French farmer called Jean, was based on a gradual crumbling of dry soils, using cultivators (GYárfás, J. 1925). The American CAMPBELL's method was discussed - both positively and negatively - in agricultural periodicals at the time. CAMPBELL, H.W. offered a solution for the tillage of dry soils, which may have been the reason for the intensive attention paid to the technique in Hungary, primarily during the years between 1909 and 1913.

Nearly a hundred articles published during those years and experiments were set up to test the special new method (Fechtig, I. 1909; Grabner, E. 1909; Káldy Szúcs, J. 1909; Kerpely, K. 1910a). The results, however, did not bear out the expectations. Reading CAMpbell's book (1907) carefully, one finds that winter wheat was sown after up to 12-14 tillage passes while it took up to 20 passes to work the soil before seeding in the spring. So many tillage passes were bound to lead to soil degradation; posterity refers to the period as the "Campbell-boom" (BırKás, M. 2003).

The anti-plough movement by Bippart (1920-1930) did have some favourable im- pacts and effects to the benefits of applying ploughless tillage from time to time it also draw attention to reasonable tillage (BEKE, L. 1922; BLAscsoK, F. 1923). The Mechwart steam plough (1893-1897) and the power tiller by Köszegi (1907-1913) have really offered a better system to cut time and energy requirements. The era of conventional tillage systems is a step back from reasonable tillage, while multiple tillage passes were still being carried out, i. e. from stubble to sowing.

The Second World War and the allocation of land to masses of landless people hampered the development of soil tillage for quite some time. In the 1950s farmers had an obligation applying deeper (more than $20 \mathrm{~cm}$ ) ploughing, which was considered to be the guarantee for higher yields. Any effort to reintroduce MANNINGER's reasonable ploughless tillage system however, was met with severe criticism (PÁter, K. 1953). Besides the difficulties, however, some progressive measures were also taken and landscape research and crop production research institutions were established or reactivated. Soil tillage experiments covering shorter or longer periods of time were started by research institutions and universities (GYóRFFY, B. 1964). At that time research and experiments were aimed at increasing yields or consolidating the stability of yields. A number of experiments were aimed at studying the optimum depth of tillage (Sipos, S. 1978).

Experimental studies of the impacts of deep tillage had probably been stimulated by the need and urge in the 1960s to increase low yields on soils that had probably been poorly tilled for quite some years by that time, along with the introduction of tools suitable for deeper tillage in the whole of the Central and Eastern European region (DrezGIC, P. and Jevtic, S. 1963). At the same time, one could not disregard publications concerning, and results achieved by, the reduction of tillage interventions (e. g. CANNELL, R.Q. 1985; Allen, R.R. and Fenster, C.R. 1986). A technique referred to as "minimum tillage" including direct drilling, was found to be of interest practically only by scientists; ex- 
periments with this system have been under way since the early 1960s (GYôRFFY, B. 1964; ZsEMBELI, J. et al. 2015).

Era of the energy saving tillage developed from fully mechanized systems with the aim of preventing additional damage and of enabling reasonable cuts in tillage costs. The steady increase of fuel prices and the advent of a dryer period had also stimulated the spreading of soil preserving techniques. Mulch tillage by disk was first adopted for use between the harvest of sunflower and the sowing of wheat, in the early 1980s, and mulch tillage by tine has adopted from the early of the 2000s (BIRKÁs, M. 2008a). A decline in the standards of soil tillage caused by the system change lasted over a period of about 10 years.

During the period of transition new opportunities for improvements in tillage are offered by encouraging the high quality production, by a new appreciation of expertise and recognition of the need for soil preservation as well as by a great variety of tillage equipment available in the market. The progress in soil tillage picked up again when new tillage systems (direct drilling, mulch-till, ridge-till, strip till, precision farming) were studied in the newly launched tillage experiments (GYôRFFY, B. 2001; Birkás, M. et al. 2009, 2015b).

\section{Conventional versus conservation tillage}

Soil tillage trends throughout the past 18 years in Hungary were evaluated with regard to the methods being used, its impact on soil condition, and the desirability for continuing to use the systems for the next two decades (Table 2).

A close correlation was found between the level of the machinery and knowledge and the tillage impacts on soil condition in both (1998 and 2011-2012) surveys. The tillage practices were grouped into three tendencies, conventional, conservation and those designed to reduce specific constraints. Conventional tillage was characterised by tilling the whole surface and using the plough as the primary tool. Achieving a soil condition suitable for crop production often requires more time than is reasonable and much higher energy costs. Furthermore, conventional tillage often has a negative effect on soil condition and the need for ineffective secondary tillage is typical.

Conventional-developing systems that consisted of those farms using up-to-date reversible plough combined with surface levelling element, and improving soil conditions by subsoiling periodically. Soils managed this way are considered free from degradation processes, disregarding a light degree of dustiness in the upper layer; the conventional-stagnating-declining systems are those where most of tillage tools and applied techniques are out-of-date and ratio of degradation (i.e. compaction and dustiness in the topsoil) reaches 50 per cent of the total area. Practices were classified as conservation tillage if the soil was not deteriorated by implements while fulfilling the carbon, water and structure preservation or if it improved the physical and biological state of the soil resource (Bırkás, M. 2011). Economically, the main feature of conservation tillage is that the soil condition for crop production can be achieved on a well-protected soil with less energy input.

The soil conservation-fully implemented category includes those tillage systems that are designed to eliminate harmful clodding, dusting, smearing or puddling. Soil conservation-partially adopted systems apply reduced or soil conservation tillage practices, but have a medium or high level of machinery. The level of soil conservation is equal to the damage imposed on the soils through the tillage operations. Systems classified as "to reduce soil constraints" are those being forced to save energy and to reduce tillage traffic because inadequate capital and appropriate equipment. An even greater problem associated with the latter systems is the imperfect level of knowledge. As a result, soil physical conditions are often deteriorated (e.g. disk-pan compaction and/or topsoil dustiness) and the biological state is typically poor (BIRKÁs, M. et al. 2004). 
Table 2. Estimated area cultivated by three types of tillage nationally and the desirable progress*

\begin{tabular}{l|c|c|c}
\hline \multirow{2}{*}{\multicolumn{1}{c|}{ Tillage types }} & \multicolumn{2}{|c|}{ Percent of adoption in } & $\begin{array}{c}\text { Desirable adoption trend in } \\
\text { the next two decades }\end{array}$ \\
\cline { 2 - 3 } & 1998 & $2011-2012$ & 25 \\
Conventional & 50 & 33 & 20 \\
Developing & 10 & 20 & 5 \\
Stagnating, declining & 40 & 13 & 68 \\
Conservation & 25 & 51 & 53 \\
Fully & 5 & 44 & 15 \\
Partially & 20 & 7 & 7 \\
To reduce soil constraints & 25 & 16 & \\
\hline
\end{tabular}

*Data from field and soil monitoring and discussed with machinery dealers and sellers.

Soil conservation tillage increased fairly in the last decade. The main factors that encouraged the adoption of conservation tillage practices - both fully and partially - were the extreme dry seasons and the economic pressures. In 1998, conservation tillage was used on 25 per cent of all tilled area and 14 years later the area cultivated by conservation way had doubled. Most of the farms were from mid-sized to large-sized and most of the owners had up-to-date knowledge in soil management. The goals for the next two decades are to substantially decrease the 'declining' and 'stagnating' pattern associated with the conventional way, and to decrease the 'reduced tillage of necessity' from 16 to 7 per cent. This trend may continue for quite a while since there will probably always be new land owners with little knowledge of the ins and outs of farming. However, the soil conservation practices will hopefully increase to approximately 68 per cent of the arable fields (Table 2).

\section{Soil quality improvement and climate threat mitigation}

The process from the beginning of the history of tillage in Hungary to the announcement of tillage aimed at reducing climate change damage was neither short, nor easy. References to extreme climate phenomena appeared in agricultural periodicals right from their earliest editions, back in the late 1800s. Weather extremes occurred in Hungary even 100-150 years ago (Milhoffer, S. 1897). The extent of damage must have been greater than today and it came without mitigation. GYÁRFÁs, J. (1925) suggested that appropriate tillage and cropping methods have to be applied to prevent damage by frequent drought.

Reviewing the articles published by periodical "Köztelek" an important fact was concluded, that is tillage problem caused by droughts were more often discussed than damage caused by too much rain. When exploring the causes of low wheat yields a classical author on soil tillage, Cserháti, S. (1902) found that low yields were caused by poor tillage because the more defects there were in the soil the more harm was caused by unfavourable weather patterns. He argued that the weather should not be used as an excuse covering up errors made in cropping. The impacts of defective soil conditions resulting in increased damage caused by droughts can be proven today too (Birkás, M. et al. 2009), although they are less frequently encountered in arable fields.

A number of authors (Rázsó, I. 1901; SzABó, J. 1909; JatTKA, F. 1910; KüZdÉNYI, Sz. 1921; Dworák, K. 1923; ToкAJI, I. 1932) emphasised that damage caused by climate conditions could be diminished, however site adopted solutions are to be applied. Cserháti (1900) and Kerpely $(1910 a, b)$ drew attention to two important requirements, facilitating the soil's water intake, and impeding evaporation from the soil, by way of tillage techniques. GYÁrfás, as a follower of CSERHÁtI, also worked on promoting reasonable tillage (Table 3 ), which is why there is an understandable similarity between their recommendations. 
Table 3. Proposals from the classic authors for soil tillage development

\begin{tabular}{|c|c|c|}
\hline \multicolumn{2}{|c|}{ Criteria of the adaptable soil tillage } & \multirow{2}{*}{$\begin{array}{l}\text { Criteria of the biological soil } \\
\text { tillage from Kemenesy (1964) }\end{array}$} \\
\hline From CsERHÁti (1900) & From GYÁRFÁs ( & \\
\hline $\begin{array}{l}\text { 1. Creating crumbly structure. } \\
\text { 2. Improving level of the nutrients } \\
\text { uptake. } \\
\text { 3. Changing soil layers from time to } \\
\text { time. } \\
\text { 4. Good mixing. } \\
\text { 5. Inverting (manure, stubble residues). } \\
\text { 6. Weed and pest control. } \\
\text { 7. Consolidation of the upper layer } \\
\text { after tillage. } \\
\text { 8. Promoting soil mellowing. } \\
\text { 9. Forming of the soil surface. }\end{array}$ & $\begin{array}{l}\text { 1. Stubble soil breaking just after } \\
\text { harvest } \\
\text { 2. Autumnal primary tillage. } \\
\text { 3. Avoiding the spring ploughing on } \\
\text { soils were ploughed in autumn. } \\
\text { 4. Creating good seedbed. } \\
\text { 5. Fallowing } \\
\text { 6. In dry conditions: } \\
\text { - Maintaining crumbly structure } \\
\text { on the soil surface; } \\
\text { - Reducing the number of plough- } \\
\text { ing. }\end{array}$ & $\begin{array}{l}\text { 1. Creating the conditions that } \\
\text { are beneficial for micro- } \\
\text { organisms by site adopted } \\
\text { soil preserving tillage and } \\
\text { organic material recycling. } \\
\text { 2. Promoting and maintaining } \\
\text { a mellowed soil state. } \\
\text { 3. Improving soil water infiltra- } \\
\text { tion and storage capacity and } \\
\text { reducing water loss (increas- } \\
\text { ing humus and water source). }\end{array}$ \\
\hline
\end{tabular}

Gyárfás listed the first five items among the fundamental tillage tasks in combating drought impacts. Item 6 can be found in his book, without his stressing, while the application of surface cover as a tillage technique was simply out of the question. Though the first - accidental - experience of surface cover was observed by KÁLDY SzüCs (1909), that report failed to attract much attention. It was not until much later that the positive impacts of the crop residue after harvest (a soil and straw mixture as a mulch) came to be proven, by Manninger (1957) and Kemenesy (1964).

Data and projections relating to climate change pose new challenges to soil tillage as well. As Szalai, S. and Lakatos, M. (2013) outlined, four main climate induced risk factors can be formulated from the optimistic and the pessimistic scenarios in the region that are milder winters with more precipitation, warmer and dry summers, extreme fluctuations in the annual distribution of the total precipitation and increased numbers of windy and stormy incidences.

Soil tillage researchers has frequently stated that the existing land use and soil tillage systems were most often based on the classic - and outdated - beliefs. Soils will really be exposed to the climate stresses. Vulnerability of soils has already become an acute problem for agricultural and environmental sustainability, and it will be even more complex problem in future decades.
Birkás, Kisic, Mesic, Jug and Kende (2015a) made a detailed proposal concerning the tasks following in the new climate situation. The main proposals are as follows. The predicted milder winters with more precipitation give chance for more water storage if the soil moisture intake capacity is maintained and improved by adaptable tillage. Any tillage intervention should be aimed at helping rainwater infiltration and at minimising the loss of water in and out of the growing season.

A relatively new challenge is the water loss from soils during colder periods, which call attention to form water preserving surface before soil wintering. Considering the possibility of dry and hot summers, the conventional soil preparation requires an evaluation from a new aspect. Rationalising soil disturbance and extending the period during which the soil is covered will be indispensable. A water managing tillage is to be combined with the organic matter conservation including $\mathrm{OM}$ recycling and carbon preserving solutions. When monitoring tillage practices, it was found that dry periods definitely promote the application of soil conservation methods and thus reducing climate risks (Table 4).

According to Birkás (2011) climate risk means the defects in the soil quality condition along with likely consequences of soil disturbance. A regrettable fact, that during wet periods - particularly in the autumn -, landowners tend to return to the convention- 
Table 4. Conservation tillage adoption in Hungary (2009-2015)*

\begin{tabular}{|c|c|c|c|}
\hline \multirow{2}{*}{ Plant and tillage task } & \multirow{2}{*}{$\begin{array}{c}\text { Area, } \\
1,000 \text { ha }\end{array}$} & \multicolumn{2}{|c|}{ Conservation tillage, $\%$} \\
\hline & & in dry seasons & in wet seasons \\
\hline Stubble tillage after summer harvest ${ }^{* *}$ & $1,590-1,670$ & $52-56$ & $37-45$ \\
\hline Primary tillage for oilseed rape & $190-250$ & $65-77$ & $52-60$ \\
\hline Primary tillage for winter wheat & $1,720-1,780$ & $52-55$ & $33-40$ \\
\hline Primary tillage for maize, sunflower & $1,620-1,770$ & $42-49$ & $27-34$ \\
\hline Primary tillage for sugar beet, soybean & $40-70$ & $60-70$ & $49-51$ \\
\hline Ploughing adaptable to wintering & 150-180 & $32-35$ & $17-24$ \\
\hline Total (without stubble tillage) & $3,570-3,870$ & $50-57$ & $36-42$ \\
\hline
\end{tabular}

*Sown area in Hungary: 4,332,000 ha (KSH, 2015), data from field and soil monitoring and discussed with machinery dealers and sellers. **Pea, rape, barley, oat, wheat, durum, triticale and rye.

al tillage methods. Accordingly, about 15 per cent of those applying soil conservation tillage methods are facing uncertainties in regard to the methods that are suitable for reducing climate-induced damage. There is difficult task to convince landowners who apply conventional methods that endanger the quality of soils. Preserving tillage of wet soils has become an acute issue during the recent decades. Dry periods have become increasingly frequent - in connection with climate forecasts - wet periods also occur primarily during the late summer and autumn tillage seasons. In spite the fact that the tillage season has expanded to the first winter month, some $36-42$ per cent of the total arable land is tilled before the soil becomes actually suitable for tillage. Applying ploughs and conventional disks and causing damage to wet soils lead to increased tillage costs during subsequent seasons.

As Birkás and Dekemati (2015b) noted that there is a demand for the elaboration of methods suitable for conservation tillage of wet soils. A brief summary of such methods is as follows: any damage already done must be remedied, while avoiding any new damage. Farmers must check their soils frequently enough to be always aware of their condition. No intervention obstructing the soil's recovery (disking or ploughing resulting in smearing and kneading the soil) should be carried out. Traffic on the soil and the number of tillage interventions must be minimised. Any compact layer blocking the water infiltration to the soil must be loosened (this method is not the same as the technique of loosening the soil with effects lasting at least one year). The soil surface must be protected to alleviate the impact of rain stress resulting in silting. Organic matter recycling and conservation is required.

\section{Crop focused tillage versus climate focused tillage}

Classical authors emphasised the importance of creating good seedbed for plants (BIRKÁs, M. 2008). In the physical approach tillage was believed to play an important role in controlling soil processes. Consequently the period of several centuries dominated by this approach is referred to as the era of crop oriented tillage (Birkás, M. et al. 2015b). References to plants' alleged tillage needs have been found in literature since the 1800s to date. Particular emphasis has been and is still often being laid on the need for creating a fine crumbly seedbed. The need for preserving the soil used to be absent from the lists of objectives of tillage in textbooks, but today it has gained primary importance (BIRKÁs, M. 2008).

The over-estimation of the importance of crop requirements resulted in damaging the soils (e.g. structure pulverisation, siltation, crust formation on the topsoil, etc.), which inevitably led to the recognition, in the mid-1960s, of the need for protecting soils quality hence that was the beginning of the era of soil focused tillage (BARTALOS, T. et al. 1995). Any crop requirements can be met by a soil kept in a good physical and biological condition by soil preserving tillage, with the added benefits of causing less damage and cutting costs. Since the first years of the climate change, as the new trends 
have raised concern, tillage must be turned into a climate focused effort with the aim of reducing climate-induced stresses through improving soil quality (Birkás, M. 2011).

\section{Conclusions}

Progress and development in soil tillage has been fraught with contradictions since the beginning of the history of tillage in Hungary. Conclusions drawn from the overview of the process:

- At the beginning progress was hindered by lack of knowledge of soil and plants, inadequate draught power and imperfect farming implements as well as natural disasters. Technical advancement could be indicated first in terms of improvements in ploughing tools and the increase in ploughing depths.

- The higher yields resulting from deeper loosened layer had associated with inverting the soil. In the absence of knowledge of the soil the damage caused by the increasingly frequent use of the plough could not be recognised.

- Up to the $20^{\text {th }}$ century the factors identified as threats to soils included - apart from wars - insufficient tillage, excessive tillage, soil depletion and drought.

- The tasks of soil protection have become highly complex in the $21^{\text {st }}$ century because, on the one hand, the process of soil degradation that has been going on for centuries needs to be brought to a halt while on the other hand, threats relating to the climate change have to be managed, with the help of adequate knowledge.

- The Hungarian soil tillage literature has made a significant impact on the progress of tillage since the 1800s, but owing to the language barrier they never came to be tested at an international level. Scientists focusing on tillage today can widely distribute their methods developed for use under difficult conditions.

Acknowledgement: Supported by the Ministry of Human Resources of Hungary. Project No VKSz12-1-2013-0034.

\section{REFERENCES}

Allen, R.R. and Fenster, C.R. 1986. Stubble-mulch equipment for soil and water conservation in the Great Plains. Journal of Soil and Water Conservation 41. 11-16.

BARoss, L. 1909. Tárcsásborona és szuperfoszfát (Disk harrow and superphosphate). Köztelek 19. 2108-2110.

Bartalos, T., Lal, R. and Németh, T. 1995. Conservation tillage for sustaining soil and water quality. Budapest, Akaprint.

BeKe, L. 1922. Az eke alkonya (Dusk of the plough). Gazdasági Lapok 74. 137-138.

Birkás, M. 1995. Energiatakarékos, talajvédő és kímélő talajmüvelés (Energy saving, soil conservation tillage). University lecture notes. Gödöllő, Szent István Univesity.

Birkás, M. 2003. A Campbell-láz Magyarországon (1908-1914). A magyar gazdák és a dry farming (The Campbell's boom in Hungary [19081914]. Hungarian farmers and the dry farming). Mezógazdasági Technika 44. (3): 39-41.

Birkás, M. ed. 2008. Environmentally-sound adaptable tillage. Budapest, Akadémiai Kiadó.

Birkás, M. 2008a. Development of soil tillage in the Pannonian region. In Environmentally-sound adaptable tillage. Ed.: Bırkás, M., Budapest, Akadémiai Kiadó, 46-48.

Birkás, M. 2008b. Lessons drawn from the history of tillage. In Environmentally-sound adaptable tillage. Ed.: BirkÁs, M., Budapest, Akadémiai Kiadó, 297-340.

BIRKÁs, M. 2011. Tillage, impacts on soil and environment. In Encyclopedia of Agrophysics. Eds.: GLINsKI, J., Нorabik, J. and Lipiec, J., Dordrecht, Springer, 903-906.

Birkás, M., Antal, J. and Dorogi, I. 1989. Conventional and reduced tillage in Hungary - A review. Soil Tillage Research 13. 233-252.

Birkás, M., Jolánkai, M., Gyuricza, C. and Percze, A. 2004. Tillage effects on compaction, earthworms and other soil quality indicators in Hungary. Soil Tillage Research 78. 185-196.

Birkás, M., Kisic, I., Bottlik, L., JolánKai, M., Mesic, M. and Kalmár, T. 2009. Subsoil compaction as a climate damage indicator. Agriculturae Conspectus Scientificus 74. (2): 1-7.

Birkás, M., Kisic, I., Mesic, M., Jug, D. and Kende, Z. 2015a. Climate induced soil deterioration and methods for mitigation. Agriculturae Conspectus Scientificus 80. (1): 17-24.

Birkás, M., Dekemati, I., Kende, Z. and Kisic, I. 2015b. Excess water phenomena - long-lasting remediation. In $8^{\text {th }}$ International Scientific Professional Conference. Agriculture in nature and environmental protection. Proceedings E Abstracts. Eds.: Baban, M. and RAsic, S., Osijek, Glas Slavonije d. d. 34-44. 
BLAscsok, F. 1923. Mi történjék az ekével? (What happen to the plough?). Köztelek 33. 327-328.

Bottlik, L., Csorba, Sz., Gyuricza, Cs., Kende, Z. and Birkás, M. 2014. Climate challenges and solutions in soil tillage. Applied Ecology and Environmental Research 12. (1): 13-23.

Campbell, H.W. 1907. Soil Culture Manual. F.F. Matenaers, Milwauke, Wisc., Hungarian translation by K. Ruffy, P., Budapest, Pátria Nyomda.

Cannell, R.Q. 1985. Reduced tillage in north-west Europe - A review. Soil and Tillage Research 5. 129-177.

Cserháti, S. 1891. A talajnak mélymüvelése hazánkban (Deep cultivation of the soil in Hungary). MagyarÓvár, Czéh S. Könyvnyomda.

Cserháti, S. 1900. Általános növénytermelés (General agronomy). Magyar-Óvár, Czéh S. Könyvnyomda.

Cserháti, S. 1902a. 7,38 q búzatermés kataszteri holdankint, I. (7.38 two hundred-weight on cadastral yoke, I.) Köztelek 12. (66): 1301-1302..

Cserháti, S. 1902a. 7,38 q búzatermés kataszteri holdankint, II. (7.38 two hundred-weight on cadastral yoke, II). Köztelek 12. (67): 1316-1318.

Drezgic, P. and Jevtic, S. 1963. The influence of depth of ploughing on the development and yield of winter wheat. Netherlands Journal of Agricultural Sciences 11. 1-157.

Dworák, K. 1923. Az eke és a talajporhanyító jelentôsége (Importance of the plough and the cultivator). Köztelek 33. 785-786.

Fechtig, I. 1909. Campbell talajmívelési módszere és a Kőszegi-féle motoros talajmívelőgép (Soil tillage method from Campbell, and the rototiller from Köszegi). Köztelek 19. 409-410.

Grabner, E. 1909. Észrevételek Campbell talajmívelési rendszeréhez (Comments to the Campbell' tillage system). Köztelek 19. 115-116.

GYÁRFÁs, J. 1925. Sikeres gazdálkodás szárazságban. A magyar dry farming (Successful farming in the drought. The Hungarian dry farming). Budapest, Pátria Nyomda.

GyốrFy, B. 1964. Hozzászólás a talaj mélymüveléséhez. (Comments to the deep tillage of the soil). Budapest, MTA Agrártudományok Osztályának közleményei 13. 362-370.

GYôRFFY, B. 2001. Javaslat a precíziós agrárgazdaság kutatási programjának indítására (Proposals for starting the precision farming research program in agriculture). Budapest, MTA Agrártudományok Osztálya 2000. évi Tájékoztatója, 17-22.

JATTKA, F. 1910. Vigyázat a mélyszántásnál! (Caution with deep ploughing!). Köztelek 20. 27-35.

KÁLDy Szúcs, J. 1909. Észrevételek Campbell talajmívelési rendszeréhez (Comments to the Campbell's tillage system). Köztelek 19, 343-344.

Kemenesy, E. 1924. A korszerü talajmüvelés irányelvei (Directives of the modern soil tillage). Budapest, Pátria Nyomda.
Kemenesy, E. 1964. Talajmüvelés (Soil tillage). Budapest, Mezőgazdasági Kiadó.

Kerpely, K. 1910a. A Campbell-féle talajmívelés (Soil tillage by Campbell). Köztelek 20. 3114-3118.

Kerpely, K. 1910b. Az okszerü talajmívelés szerepe a szárazság elleni küzdelemben (The role of rational soil cultivation in fight against drought). Budapest, Pátria Nyomda.

KüZDÉNYI, Sz. 1921. A talajmüvelésröl, különös tekintettel a szikes talajok javitására (Soil tillage, especially for improvement of the saline soils).Mezőtúr, Borbély Gy. Nyomda.

Manninger, G.A. 1938. A kultivátor, mint egyetemes müvelő-szerszám (The cultivator, as an universal tillage tool). In A tarlótól a magágyig. Ed.: Marschall, F., Budapest, Révai Nyomda, 84-90.

Manninger, G.A. 1957. A talaj sekély müvelése (The shallow soil tillage). Budapest, Mezőgazdasági Kiadó.

Milhoffer, S. 1897. Talajkimerülés (Soil exhaustion). Budapest, Könyves Kálmán Rt.

PÁter, K. 1953. Bevezető előadás. A mélyszántás kérdései (Introductory lecture. Questions in the deep ploughing). Budapest, MTA Agrártudományok Osztályának közleményei 2. 109-133.

Pethe, F. 1818. Magyar Szántóvető (The Hungarian Plough-Planter). Nemzeti Gazda 5. 1-12.

RÁzsó, I. 1901. Az idő-e a gazda, vagy a gazda az idő? (The weather is the farmer, or the farmer is the weather?) Köztelek 11. 13-33.

Schertz, D.L. 1988. Conservation tillage: An analyis of acreage projections in the United States. Journal of Soil and Water Conservation 43. 256-258.

Sedlmayr, K. 1954. Hozzászólás. Harc a sematizmus ellen (Comments. Fight against schematic practice). Állami Gazdaságok 6. (13-14): 3-9.

Sipos, S. 1978. A periódusos mélyítő müvelés rendszere (Periodical deep tillage system). In Földmüveléstan. Ed.: LőrInCz, J., Budapest, Mezőgazdasági Kiadó, 254-258.

Stefanovits, P. 1981. Talajtan (Soil science). Budapest, Mezőgazdasági Kiadó.

Szaвó, J. 1909. Gyönge búzatermések okai (Reasons of the poor harvest). Köztelek 19. 2056-2057.

Szalai, S. and Lakatos, M. 2013. Precipitation climatology of the Carpathian Region and its effects on the agriculture. Növénytermelés 62. 315-318.

ToKAJI, I. 1932. A legutóbbi évek száraz időjárásának tanulságai (Evidences of the dry weather in the last years). Köztelek 42. 351-352.

VÁRALlYAY, GY. 1989. Soil degradation processes and their control in Hungary. Land Degradation and Rehabilitation 1. 171-178.

Zsembeli, J., Szúcs, L., Tuba, G. and Czimbalmos, R. 2015. Nedvességtakarékos talajmúvelési rendszer fejlesztése Karcagon (Improvement of the water conservation soil tillage systems in Karcag). In Környezetkímélő talajmüvelési rendszerek Magyarországon. Ed.: Madarász, B., Budapest, MTA CSFK Földrajztudományi Intézet, 122-133. 